\title{
Nitrogen partitioning and microbial protein synthesis in lactating dairy cows with different phenotypic residual feed intake
}

\author{
Yunyi Xie, Zezhong Wu, Diming Wang and Jianxin Liu* (D)
}

\begin{abstract}
Background: Residual feed intake (RFI) is an inheritable measure of feed efficiency that is independent on level of production. However, physiological and metabolic mechanisms underlying divergent RFI are not fully elucidated. This study was conducted to investigate dietary nitrogen $(\mathrm{N})$ partitioning and microbial protein synthesis in lactating dairy cows divergent in phenotypic RFI.

Results: Thirty Holstein dairy cows (milk yield $=35.3 \pm 4.71 \mathrm{~kg} / \mathrm{d}$; milk protein yield $=1.18 \pm 0.13 \mathrm{~kg} / \mathrm{d}$; mean \pm standard deviation) were selected for the experiment to derive RFI. After the RFI measurement period of $50 \mathrm{~d}$, the 10 lowest RFI cows and 8 highest RFI cows were selected. The low RFI cows had lower dry matter intake $(\mathrm{DMl}, P<0.05)$ than the high RFI cows, but they produced similar energy-corrected milk. The ratios of milk to DMI $(1.41$ vs. $1.24, P<0.01)$ and energy-corrected milk to DMI (1.48 vs. 1.36, $P<0.01)$ were greater in low RFI cows than those in the high RFI cows. The low RFI cows had lower milk urea nitrogen than that in the high RFI cows $(P=0.05)$. Apparent digestibility of nutrients did not differ between two groups ( $P>0.10)$. Compared with high RFI animals, the low RFI cows had a lower retention of $\mathrm{N}(5.72$ vs. $51.4 \mathrm{~g} / \mathrm{d}, P<0.05)$ and a higher partition of feed $\mathrm{N}$ to milk $\mathrm{N}(29.7 \% \mathrm{vs.} 26.5 \%, P<0.05)$.
\end{abstract}

Conclusions: The results suggest that differences in $\mathrm{N}$ partition, synthesis of microbial protein, and utilization of metabolizable protein could be part of the mechanisms associated with variance in the RFI.

Keywords: Lactating cows, Microbial protein, Nitrogen partitioning, Residual feed intake

\section{Background}

The optimization of milk production (especially milk protein) per kilogram of feed consumed is important to dairy farmers [1]. Residual feed intake (RFI) is a measure of feed efficiency and defined as the difference between the expected and actual feed intake to support maintenance and production over a specific production period [2]. There is growing evidence that feed efficiency is different even in high-efficiency herds that feed the same diet [3]. The low RFI (efficient) cows are those that consume less feed than the expected for maintenance and production, compared with the high RFI cows, and RFI is a heritable trait for dairy cows [4-6]. Several mechanisms have been suggested to explain the causes of variation in RFI between dairy cows, including rumen microbial populations [7], feeding behavior

\footnotetext{
*Correspondence: liujx@zju.edu.cn

Institute of Dairy Science, MOE Key Laboratory of Molecular Animal Nutrition, College of Animal Sciences, Zhejiang University, Hangzhou 310058, People's Republic of China
}

$[8,9]$ and nutrients digestibility $[10,11]$. Understanding the mechanisms for different RFI in dairy cows may help dairy industry make informed breeding decisions.

Variation in the RFI of lactating cows may be related to nitrogen $(\mathrm{N})$ partitioning. It is reported that apparent $\mathrm{N}$ digestibility is greater for lower RFI animals $[10,12]$. Furthermore, the RFI variation in cattle could be explained by variation in rumen-related functions such as feed degradation and microbial protein (MCP) synthesis, suggesting the vital role of rumen for divergence in RFI. Microbial protein has a major impact on the quantity and quality of the metabolizable protein (MP) that is delivered to and absorbed from the small intestines [13]. The improvement of efficiency of MCP synthesis is important because it allows dairy cows to optimize the protein available to the animals.

Milk protein yield is crucial milk performance trait of dairy cows that directly affect the dairy profits. Thus, we hypothesized that individual variation exists for RFI in 
the relatively higher milk-protein-yielding cows. In these cows, low RFI animals would produce MCP and use MP more efficiently than the high RFI cows. Thus, the objective of this study was to identify which processes, from intake to milk protein secretion, contribute to the differences in the RFI.

\section{Materials and methods}

\section{Animals and management}

All experimental procedures involving animals were approved by the Animal Care Committee of Zhejiang University (Hangzhou, China). Thirty lactating Holstein cows $(\mathrm{BW}=749 \pm 74.6 \mathrm{~kg}$, days-in-milk $=189 \pm 18.9 \mathrm{~d}$; mean \pm standard derivation) were selected for the experiment. These cows had relatively higher milk yield $(35.9 \pm 4.20$ $\mathrm{kg} / \mathrm{d})$ and milk protein content $(3.29 \% \pm 0.22 \%)$. The trial lasted for $57 \mathrm{~d}$, with the first $7 \mathrm{~d}$ used for adaptation. The cows were fed total mixed ration that was formulated to produce $35 \mathrm{~kg}$ of milk a day with $3.25 \%$ of milk protein based on the NRC recommendation [13], and the ration ingredient is shown in Table 1. Feed intake data was collected using automatic weighing troughs (Roughage Intake Control System, Marknesse, The Netherlands). Each feeding station included an individual identification system that allowed each cow to enter a specific feeding bunk and

Table 1 Ingredient composition of the total mixed rations

\begin{tabular}{|c|c|c|c|}
\hline Ingredient & $\%$ (DM basis) & Nutrient levels ${ }^{a}$ & $\%$ of $\mathrm{DM}$ \\
\hline Alfalfa hay & 16.1 & $\mathrm{DM}$ & 51.8 \\
\hline Oat hay & 7.55 & $\mathrm{OM}$ & 95.5 \\
\hline Corn silage & 18.8 & $C P$ & 16.0 \\
\hline Brewer's grains & 3.47 & NDF & 32.9 \\
\hline Beet pulp & 4.67 & ADF & 19.0 \\
\hline Cottonseed meal, whole & 5.49 & $\mathrm{NE}_{\mathrm{L}}, \mathrm{Mcal} / \mathrm{kg} \mathrm{DM}$ & 1.70 \\
\hline Steam-flaked corn & 5.57 & & \\
\hline Ground corn grain & 17.0 & & \\
\hline Soybean meal & 9.62 & & \\
\hline Expanded soybean & 2.74 & & \\
\hline Fat meal & 1.09 & & \\
\hline $\mathrm{DDGS}^{\mathrm{b}}$ & 4.62 & & \\
\hline $\mathrm{CaHPO}_{4}$ & 0.11 & & \\
\hline $\mathrm{NaCl}$ & 0.21 & & \\
\hline Limestone & 0.36 & & \\
\hline $\mathrm{NaHCO}_{3}$ & 0.34 & & \\
\hline $\mathrm{MgO}$ & 0.13 & & \\
\hline Premix ${ }^{c}$ & 2.12 & & \\
\hline
\end{tabular}

${ }^{a} D M$ dry matter, $O M$ organic matter, $C P$ crude protein, NDF neutral detergent fiber, $A D F$ acid detergent fiber, $N E_{L}$, net energy for lactation, estimated according to the NRC recommendation [13]

${ }^{\mathrm{b}}$ DGGS Distillers Dried Grains with Solubles

'Premix, formulated to provide (per kg of DM): vitamin $\mathrm{A} \geq 600 \mathrm{kJU}$, vitamin $\mathrm{D}_{3} \geq 150 \mathrm{kIU}$, vitamin $\mathrm{E} \geq 2,000 \mathrm{IU}$, nicotinic acid $\geq 500 \mathrm{mg}, \mathrm{Cu} \geq 1500 \mathrm{mg}, \mathrm{Fe} \geq$ $1,500 \mathrm{mg}, \mathrm{Mn} \geq 1,500 \mathrm{mg}, \mathrm{Zn} \geq 7,000 \mathrm{mg}, \mathrm{I} \geq 90 \mathrm{mg}$, Se $\geq 50 \mathrm{mg}, \mathrm{Co} \geq 20 \mathrm{mg}$ automatically recorded each meal. The cows were milked three times daily at 06:30, 14:00 and 21:30 h, fed three times daily at $07: 00,14: 30$ and $22: 00 \mathrm{~h}$ to enable ad libitum intake with $5 \%$ to $10 \%$ refusal, and had free access to drinking water. The feed residual was discarded daily before the morning feeding.

\section{Sample collection and measurements}

Samples of the ration were collected weekly, and spot fecal samples (approximately $500 \mathrm{~g}$ ) were collected from the rectum of each cow 3 times per day at 06:00, 12:00, and 18:00 h on d 24-25 and d 49-50 of the feeding period. The samples were dried at $65^{\circ} \mathrm{C}$ for $48 \mathrm{~h}$ and then ground through a 1-mm screen in a Cyclotec mill (Tecator 1093; Tecator AB, Hoganas, Sweden) for later analysis. All the samples were analyzed for dry matter (DM, method No. 934.01), crude protein (CP, method No. 988.05), crude ash (method No. 942.05), and acid detergent fiber (ADF, method No. 973.18) according to AOAC methods [14]. The content of neutral detergent fiber (NDF) content was analyzed by the method of Van Soest et al. [15]. Chemical composition of the diet is listed in Table 1.

The in situ rumen DM and CP degradation of diet sample was determined through the ruminal incubation of samples for $2,4,8,12,16,24,36$, and $48 \mathrm{~h}$ according to the method described by Wang et al. [16]. The residues and original diet samples were analyzed for DM and CP. The DM and CP degradation contents are listed in Additional file 1: Table S1. Indigestible NDF (iNDF, 12-day ruminal incubation in $25-\mu \mathrm{m}$-pore-size bags) was used as an intrinsic marker to estimate fecal excretion and nutrient digestibility and was determined according to the methods of Lee and Hristov [17].

Milk yields from all cows were recorded at each milking. Milk samples were collected weekly for consecutive two days at a proportion of 4:3:3 according to three times of milking by using composite milk samplers. Bronopol tablets (milk preservative, D \& F Control Systems, San Ramon, CA) were added to the composite milk samples, which were stored at $4{ }^{\circ} \mathrm{C}$ for future analysis of protein, fat, lactose, milk urea nitrogen (MUN), total solids (TS), and somatic cell counts (SCC) using a spectrophotometer (Foss-4000; Foss Electric A/S, Hillerød, Denmark).

On d 24 and 49 of the feeding period, rumen fluid (50 $\mathrm{mL}$ ) was collected using an oral stomach tube approximately $3 \mathrm{~h}$ after the morning feeding, as described by Shen et al. [18]. The $\mathrm{pH}$ of the rumen fluid was immediately measured using a portable $\mathrm{pH}$ meter (FE20-FiveEasy Plus ${ }^{\mathrm{mw}}$; Mettler Toledo Instruments Co. Ltd., Shanghai, China). The samples were placed on ice and kept stationary while the supernatant separated, and then, the samples were frozened at $-20^{\circ} \mathrm{C}$ for future determination of volatile fatty acid (VFA). Two $\mathrm{mL}$ of rumen sample was acidified with 
$20 \mu \mathrm{L}$ of $25 \%$ orthophosphate acid and then centrifuged at $20,000 \times g$ for $10 \mathrm{~min}$ at $4{ }^{\circ} \mathrm{C}$. The supernatant was then subjected to VFA measurement using a gas chromatograph (GC-2010, Shimadzu, Kyoto, Japan) according to the methods described previously [19].

Blood samples were obtained from the coccygeal vein of each cow into procoagulation $10 \mathrm{~mL}$ tubes approximately $3 \mathrm{~h}$ after feeding on d 24 and $\mathrm{d} 49$ of experimental period. The samples were then centrifuged at $3,000 \times g$ for $15 \mathrm{~min}$ to collect serum and were frozen at $-20^{\circ} \mathrm{C}$ until analysis. Serum samples were analyzed using an autoanalyzer 7020 (Hitachi High-Technologies Corp., Tokyo, Japan) for total plasma protein, albumin, globulin, urea nitrogen, creatinine, glucose, nonesterified fatty acids (NEFA), triglycerides, cholesterol, alkaline phosphatase (ALP), aspartate aminotransferase (AST), alanine aminotransferase (ALT) and total bilirubin, according to the method described by Richardson et al. [20].

Cows were weighed weekly immediately before the morning feeding. The average daily gain (ADG) was calculated based on the difference between the BW on the first day and the last day during the experimental period.

\section{Calculation of MCP and MP}

Urinary purine derivatives $(\mathrm{PD})$ were used to indirectly estimate the MCP flow in the rumen [21]. Spot urine samples were collected on d 24-25 and d 49-50, i.e., d 24 and 49, 08:00, 16:00 and 24:00 h; d 25 and 50, 12:00, 20:00 and 04:00 $\mathrm{h}$. Collected urine samples were pooled by cow, and $15 \mathrm{~mL}$ of each subsample was acidified with $60 \mathrm{~mL}$ of $0.036 \mathrm{~mol} / \mathrm{L} \mathrm{H}_{2} \mathrm{SO}_{4}$ and immediately stored at $-20^{\circ} \mathrm{C}$ for later analysis of the PD [21]. Creatinine was analyzed using a colorimetric picric acid assay [22]. Creatinine has been validated as a marker to estimate urine volume [23] and was assumed to be excreted at a rate of $29 \mathrm{mg} / \mathrm{kg}$ of BW [24]. The intestinally absorbable dietary protein (IADP) was estimated by the following equation: IADP $=\mathrm{RUP} \times \mathrm{CP}$ intake $\times$ IDP, where IDP is the intestinal digestibility of rumen undegraded protein (RUP), which was determined from the residue of feedstuff incubated in the rumen for 16 $\mathrm{h}$, according to a modified 3-step procedure [25].

\section{RFI computation}

The expected feed intake was calculated based on methods developed for lactating dairy cattle [6]. Stepwise multiple linear regression analysis was used to establish the regression equation:

$$
Y_{\mathrm{i}}=\beta_{0}+\beta_{1} \mathrm{ECM}_{\mathrm{i}}+\beta_{2} \mathrm{BW}^{0.75}{ }_{\mathrm{i}}+\beta_{3} \mathrm{ADG}+e_{i},
$$

where $Y_{\mathrm{i}}$ is the expected feed intake $(\mathrm{kg} / \mathrm{d})$ of the $i$ th ani$\mathrm{mal}, \beta_{0}$ is the regression intercept, $\beta_{1}$ is the partial regression coefficient for energy-corrected milk yield (ECM, kg/ d), $\beta_{2}$ is the partial regression coefficient for metabolic
BW (BW $\left.{ }^{0.75}, \mathrm{~kg}\right), \beta_{3}$ is the partial regression coefficient for ADG $(\mathrm{kg})$, and $e_{i}$ is the random error associated with the $i^{\text {th }}$ animal.

The RFI for each animal was calculated as the difference between the actual and expected average feed intakes during the trial. Cows with RFI $>0.3 \mathrm{SD}$ above the mean of 0 were categorized as the "low-efficiency group" and defined as high RFI; those with RFI $>0.3$ SD below the mean were categorized as the "high-efficiency group" and defined as low RFI. Thus, there were 10 and 8 cows in low- and high-RFI groups, respectively. The days-in-milk, parity and body weight of the cows for two groups are shown in Table 2.

\section{Statistical analysis}

Data on lactation performance, digestibility, $\mathrm{N}$ conversion, urinary $\mathrm{PD}$, and rumen fermentation variables were analyzed using PROC MIXED of SAS (SAS Institute, 2000). The model included the fixed effects of the RFI group (high and low), week, group $\times$ week, and random effects of the

Table 2 Productivity of lactating cows selected for phenotypic divergence in residual feed intake (RFI)

\begin{tabular}{|c|c|c|c|c|c|c|}
\hline \multirow[t]{2}{*}{ Items } & \multirow{2}{*}{$\begin{array}{l}\text { Low } \\
\text { RFI }\end{array}$} & \multirow{2}{*}{$\begin{array}{l}\text { High } \\
\text { RFI }\end{array}$} & \multirow[t]{2}{*}{ SEM } & \multicolumn{3}{|c|}{$P$ value $^{a}$} \\
\hline & & & & $\mathrm{RFI}$ & Day & RFI $\times$ Day \\
\hline Number, head & 10 & 8 & & & & \\
\hline \multicolumn{7}{|l|}{ Lactation performance ${ }^{b}$} \\
\hline $\mathrm{DMl}, \mathrm{kg} / \mathrm{d}$ & 24.2 & 26.6 & 0.68 & 0.02 & $<0.01$ & 0.32 \\
\hline Milk yield, kg/d & 34.0 & 33.1 & 1.39 & 0.65 & $<0.01$ & 0.96 \\
\hline Milk protein yield, kg/d & 1.11 & 1.10 & 0.05 & 0.90 & 0.03 & 0.91 \\
\hline $\mathrm{ECM}, \mathrm{kg} / \mathrm{d}$ & 35.7 & 36.4 & 1.35 & 0.72 & $<0.01$ & 0.85 \\
\hline ECM/DMl, kg/kg & 1.48 & 1.36 & 0.03 & $<0.01$ & $<0.01$ & 0.77 \\
\hline Milk/DMl, kg/kg & 1.41 & 1.24 & 0.04 & $<0.01$ & $<0.01$ & 0.64 \\
\hline $\mathrm{RFI}, \mathrm{kg} / \mathrm{d}$ & -0.96 & 1.18 & 0.22 & $<0.01$ & - & - \\
\hline \multicolumn{7}{|l|}{ Milk composition ${ }^{c}$} \\
\hline Milk fat, \% & 3.83 & 4.23 & 0.12 & 0.01 & 0.05 & 0.87 \\
\hline Milk protein, \% & 3.26 & 3.33 & 0.06 & 0.40 & $<0.01$ & 0.64 \\
\hline Lactose, \% & 4.97 & 4.90 & 0.03 & 0.21 & $<0.01$ & 0.15 \\
\hline Total solids, \% & 12.7 & 13.0 & 0.14 & 0.12 & 0.12 & 0.90 \\
\hline MUN, mg/dL & 12.7 & 13.9 & 0.39 & 0.05 & $<0.01$ & 0.62 \\
\hline $\mathrm{SCC}, \times 10^{3} / \mathrm{mL}$ & 50.5 & 38.7 & 9.46 & 0.39 & 0.33 & 0.46 \\
\hline Days in milk & 193 & 182 & 6.30 & 0.22 & - & - \\
\hline Parity & 2.70 & 2.50 & 0.22 & 0.56 & - & - \\
\hline Body weight, kg & 739 & 737 & 16.7 & 0.96 & $<0.01$ & 0.24 \\
\hline Average dairy gain, kg & 0.17 & 0.26 & 0.18 & 0.66 & 0.08 & 0.68 \\
\hline
\end{tabular}

${ }^{\mathrm{a}} P$ value associated with $\mathrm{RFI}$, time, and the interaction of $\mathrm{RFI}$ and time ${ }^{b} \mathrm{DMl}$, dry matter intake; ECM $(\mathrm{kg})=0.3246 \times$ milk yield $(\mathrm{kg})+13.86 \times$ milk fat $(\mathrm{kg})+7.04 \times$ milk protein $(\mathrm{kg})$ [44]. All cows remained pregnant during the trial ${ }^{\mathrm{C}} \mathrm{MUN}$ milk urea nitrogen, SCC somatic cell counts 
cow. The statistical significance was declared at $P \leq 0.05$ and trends were indicated at $0.05<P \leq 0.10$.

\section{Results}

\section{Milk production}

Milk yield, milk composition, BW and ADG of the lactating cows are summarized in Table 2. No differences were observed in the BW $(P=0.96)$ and ADG $(P=0.66)$ between higher and low RFI cows. The low RFI cows consumed $2.45 \mathrm{~kg}$ DM/d less than the high RFI animals $(P=0.02)$, but cows in both groups produced similar milk yield $(P=0.65)$, milk protein yield $(P=0.90)$ and ECM $(P=0.72)$. Low RFI cows had a lower content of milk fat $(P=0.01)$ and MUN $(P=0.05)$ than that of high RFI cows. The ratios of milk to DMI and ECM to DMI were greater in the low RFI cows than those in the high RFI cows $(P<0.01)$. The day of sampling had a significant $(P<0.05)$ effect on the milk yield and milk composition except for the total solids $(P=0.12)$ and SCC $(P=$ $0.33)$.

\section{Rumen fermentation parameters and apparent digestibility}

The rumen fermentation parameters and apparent digestibility of the lactating cows are listed in Table 3 . The concentration of propionate was lower in low RFI group compared with that in the high RFI ones $(P=0.04$, data not shown). However, there was no difference in the rumen $\mathrm{pH}(P=0.35)$, total VFA $(P=0.18)$, the molar proportions of individual VFA $(P>0.10)$ and apparent digestibility $(P>0.10)$ between the two groups.

\section{Plasma variables}

The results of the plasma variables are listed in Table 4. High RFI cows tended to have higher concentrations of triglycerides $(P=0.09)$ and ALT $(P=0.08)$ than those in low RFI cows. No differences were found in the other plasma variables $(P>0.10)$ between the two groups, with no interaction of day and RFI.

\section{Microbial protein production}

The results of the IADP, urinary PD, estimated MCP and MP are presented in Table 5 . No differences were observed in the urinary PD $(P=0.86)$, estimated $\mathrm{MCP}(P=$ $0.86)$ and MP $(P=0.47)$. However, the amount of IADP tended to be greater in the high RFI group $(P=0.06)$ than that in the low RFI animals. The efficiency of rumen MCP synthesis was similar between the high and low RFI cows $(P>0.05)$. The low RFI cows had a greater proportion of dietary protein secreted into milk $(P<$ 0.05) than that in the high RFI cows.
Table 3 Rumen pH, volatile fatty acids (VFA), and apparent digestibility of lactating cows selected for phenotypic divergence in residual feed intake (RFI)

\begin{tabular}{|c|c|c|c|c|c|c|}
\hline \multirow[t]{2}{*}{ Items } & \multirow{2}{*}{$\begin{array}{l}\text { Low } \\
\text { RFI }\end{array}$} & \multirow{2}{*}{$\begin{array}{l}\text { High } \\
\text { RFI }\end{array}$} & \multirow[t]{2}{*}{ SEM } & \multicolumn{3}{|c|}{$P$ value $^{a}$} \\
\hline & & & & RFI & Day & RFI $\times$ Day \\
\hline $\mathrm{pH}$ & 6.41 & 6.30 & 0.08 & 0.35 & 0.54 & 0.86 \\
\hline Total VFA, mmol/L & 101 & 108 & 3.84 & 0.18 & 0.21 & 0.22 \\
\hline \multicolumn{7}{|c|}{ Molar proportion, $\mathrm{mmol} / 100 \mathrm{mmol}$} \\
\hline Acetate (A) & 65.1 & 64.2 & 0.86 & 0.46 & 0.28 & 0.61 \\
\hline Propionate $(P)$ & 20.2 & 21.5 & 0.94 & 0.36 & 0.08 & 0.40 \\
\hline Butyrate & 11.1 & 10.8 & 0.39 & 0.71 & 0.17 & 0.87 \\
\hline Isobutyrate & 0.72 & 0.68 & 0.04 & 0.44 & $<0.01$ & 0.43 \\
\hline Valerate & 1.45 & 1.45 & 0.05 & 0.98 & $<0.01$ & 0.30 \\
\hline Isovalerate & 1.45 & 1.30 & 0.08 & 0.21 & 0.06 & 0.71 \\
\hline A: $P$ ratio & 3.29 & 3.11 & 0.18 & 0.46 & 0.07 & 0.40 \\
\hline \multicolumn{7}{|c|}{ Apparent digestibility ${ }^{b}$} \\
\hline DM, \% & 64.0 & 64.4 & 0.87 & 0.73 & 0.12 & 0.43 \\
\hline$C P, \%$ & 65.4 & 66.2 & 1.55 & 0.73 & 0.24 & 0.69 \\
\hline NDF, \% & 35.9 & 35.4 & 1.02 & 0.74 & 0.02 & 0.22 \\
\hline$A D F, \%$ & 33.7 & 32.9 & 1.06 & 0.60 & 0.30 & 0.28 \\
\hline
\end{tabular}

${ }^{\mathrm{a}} P$ value associated with $\mathrm{RFI}$, time, and the interaction of RFI and time ${ }^{\mathrm{b}} D M$ dry matter, $C P$ crude protein, NDF neutral detergent fiber, $A D F$ acid detergent fiber

Table 4 Plasma variables of lactating cows selected for phenotypic divergence in residual feed intake (RFI)

\begin{tabular}{|c|c|c|c|c|c|c|}
\hline \multirow[t]{2}{*}{ Items $^{a}$} & \multirow{2}{*}{$\begin{array}{l}\text { Low } \\
\text { RFI }\end{array}$} & \multirow{2}{*}{$\begin{array}{l}\text { High } \\
\text { RFI }\end{array}$} & \multirow[t]{2}{*}{ SEM } & \multicolumn{3}{|c|}{$P$ value ${ }^{b}$} \\
\hline & & & & $\overline{\mathrm{RFI}}$ & Day & $\overline{R F I \times \text { Day }}$ \\
\hline \multicolumn{7}{|l|}{ Protein metabolism } \\
\hline Total protein, g/L & 70.8 & 71.8 & 0.99 & 0.51 & 0.75 & 0.39 \\
\hline Albumin (A), g/L & 26.7 & 27.6 & 0.41 & 0.12 & 0.78 & 0.54 \\
\hline Globulin (G), g/L & 44.2 & 44.2 & 1.02 & 0.99 & 0.81 & 0.51 \\
\hline$A / G$ & 0.61 & 0.63 & 0.02 & 0.39 & 0.92 & 0.69 \\
\hline $\mathrm{BUN}, \mathrm{mmol} / \mathrm{L}$ & 5.63 & 6.23 & 0.31 & 0.18 & 0.21 & 0.18 \\
\hline Creatinine, $\mu \mathrm{mol} / \mathrm{L}$ & 74.9 & 72.2 & 2.27 & 0.38 & 0.17 & 0.43 \\
\hline \multicolumn{7}{|l|}{ Energy substrates } \\
\hline Glucose, mmol/L & 3.61 & 3.48 & 0.09 & 0.35 & 0.42 & 0.61 \\
\hline NEFA, $\mu \mathrm{mol} / \mathrm{L}$ & 118 & 109 & 6.79 & 0.35 & 0.01 & 0.10 \\
\hline Triglyceride, $\mu \mathrm{mol} / \mathrm{L}$ & 0.17 & 0.28 & 0.04 & 0.09 & 0.75 & 0.95 \\
\hline Cholesterol, mmol/L & 7.98 & 7.55 & 0.27 & 0.27 & 0.11 & 0.42 \\
\hline \multicolumn{7}{|l|}{ Liver function } \\
\hline $\mathrm{ALT}, \mathrm{U} / \mathrm{L}$ & 26.2 & 28.3 & 0.80 & 0.08 & 0.27 & 0.71 \\
\hline AST, U/L & 91.4 & 88.7 & 5.00 & 0.71 & 0.43 & 0.85 \\
\hline$A L P, U / L$ & 34.6 & 47.0 & 5.14 & 0.11 & 0.13 & 0.26 \\
\hline Total bilirubin, $\mu \mathrm{mol} / \mathrm{L}$ & 1.56 & 1.49 & 0.06 & 0.43 & 0.49 & 0.64 \\
\hline
\end{tabular}

${ }^{a} B U N$ blood urea nitrogen, NEFA nonesterified fatty acids, $A L T$ alanine aminotransferase, AST aspartate aminotransferase, ALP alkaline phosphatase ${ }^{\mathrm{b}} P$ value associated with $\mathrm{RFI}$, time, and the interaction of RFI and time 
Table 5 The urinary purine derivatives (PD) and estimated MP supply to the dairy cows selected for phenotypic divergence in residual feed intake (RFI)

\begin{tabular}{|c|c|c|c|c|c|c|}
\hline \multirow[t]{2}{*}{ Items } & \multirow{2}{*}{$\begin{array}{l}\text { Low } \\
\text { RFI }\end{array}$} & \multirow{2}{*}{$\begin{array}{l}\text { High } \\
\text { RFI }\end{array}$} & \multirow[t]{2}{*}{ SEM } & \multicolumn{3}{|c|}{$P$ value $^{a}$} \\
\hline & & & & $\overline{\mathrm{RFI}}$ & Day & RFI $\times$ Day \\
\hline Urine volume ${ }^{b}, L / d$ & 33.6 & 33.4 & 2.64 & 0.96 & $<0.01$ & 0.07 \\
\hline \multicolumn{7}{|l|}{ Urinary PD, mmol/d } \\
\hline Allantoin & 489 & 520 & 33.1 & 0.51 & 0.60 & 0.16 \\
\hline Uric acid & 39.4 & 51.1 & 4.80 & 0.11 & 0.09 & 0.40 \\
\hline Endogenous PD & 54.2 & 49.9 & 2.87 & 0.31 & 0.29 & 0.23 \\
\hline Sum & 474 & 484 & 40.2 & 0.86 & 0.70 & 0.77 \\
\hline$M C P^{c}, g / d$ & 2152 & 2198 & 183 & 0.86 & 0.70 & 0.78 \\
\hline IADPd,$g / d$ & 695.5 & 760.8 & 22.5 & 0.06 & 0.07 & 0.80 \\
\hline$M P^{e}, g / d$ & 2065 & 2171 & 100.2 & 0.47 & 0.36 & 0.58 \\
\hline
\end{tabular}

${ }^{a} P$ value associated with $\mathrm{RFI}$, time, and the interaction of $\mathrm{RFI}$ and time

burine volume $(\mathrm{L} / \mathrm{d})=B W(\mathrm{~kg}) \times 29(\mathrm{mg} / \mathrm{d}) / \mathrm{creatinine}(\mathrm{mg} / \mathrm{L})[24]$

${ }^{\mathrm{C}}$ Microbial protein (MCP) was indirectly estimated by the equation [21]: $\mathrm{MCP}=$ (allantoin + uric acid - endogenous

PD) $\times 70 \times 6.25 /(0.116 \times 0.83 \times 1000)$

${ }^{d}$ Intestinally absorbable dietary protein $(I A D P)=R U P \times C P$ intake $\times$ IDP, where IDP is the measured intestinal digestibility of rumen undegraded protein (RUP). The feedstuff incubated in the rumen for $16 \mathrm{~h}$ was used to determine the IDP according to a modified 3-step procedure [25]

${ }^{e} \mathrm{MP}=\mathrm{IAMCP}+\mathrm{IADP} ; \mathrm{IAMCP}=$ Intestinally absorbable $\mathrm{MCP}=\mathrm{MCP} \times 0.64$ [13]

\section{Partitioning of nitrogen}

Nitrogen intake in high RFI cows tended to be greater than that in the low RFI cows $(P=0.06$, Table 6$)$. When expressed as a percentage of dietary $\mathrm{N}$ intake, $\mathrm{N}$ in milk was greater in low RFI (efficient) cows than in the high RFI cows $(P=0.02)$, but the $\mathrm{N}$ retained in the low RFI cows tended to be less than that in the high RFI cows $(P=0.06)$. However, the output of urine $(P=0.31)$ and feces $(P=0.91)$ and their proportion of dietary $\mathrm{N}(P>$ 0.05 ) were not different between the two groups.

Table 6 Nitrogen output and partitioning in lactating cows selected for phenotypic divergence in residual feed intake (RFI)

\begin{tabular}{lllllll}
\hline Items & $\begin{array}{l}\text { Low } \\
\text { RFI }\end{array}$ & $\begin{array}{l}\text { High } \\
\text { RFI }\end{array}$ & SEM & \multicolumn{4}{l}{$P$ value $^{\text {a }}$} \\
\cline { 5 - 7 } & & & & RFI & Day & RFI $\times$ Day \\
\hline N intake, g/d & 590 & 644 & 18.6 & 0.06 & 0.01 & 0.92 \\
N output, g/d & & & & & & \\
$\quad$ Feces & 202 & 218 & 10.3 & 0.31 & 0.77 & 0.64 \\
Urine & 206 & 204 & 13.1 & 0.91 & 0.15 & 0.59 \\
Milk & 175 & 171 & 8.42 & 0.75 & $<0.01$ & 0.59 \\
Retention ${ }^{b}$ & 5.72 & 51.4 & 14.1 & 0.04 & 0.15 & 0.82 \\
\% of N intake & & & & & & \\
Feces & 34.6 & 33.8 & 1.55 & 0.73 & 0.24 & 0.69 \\
Urine & 35.1 & 32.3 & 2.28 & 0.39 & 0.03 & 0.80 \\
Milk & 29.7 & 26.5 & 0.89 & 0.02 & 0.22 & 0.71 \\
Retention & 0.37 & 7.08 & 2.50 & 0.06 & 0.17 & 0.86 \\
\hline
\end{tabular}

${ }^{a} P$ value associated with $\mathrm{RFI}$, time, and the interaction of $\mathrm{RFI}$ and time

${ }^{\mathrm{b}}$ Nitrogen retention $=$ ingested $\mathrm{N}-$ fecal $\mathrm{N}-$ urinary $\mathrm{N}-$ milk $\mathrm{N}$

\section{Discussion}

With regard to the efficiency of $\mathrm{N}$ utilization in dairy cows, it is needed to consider the conversion of dietary CP into MP (due to differences in digestibility, ruminal fermentation, and absorption of nutrients, etc.) and the subsequent efficiency of MP conversion to milk protein. The MP is the milk protein precursor and its yield is closely related to milk and milk protein yield [13]. In our study, the increased tendency for IADP in the high RFI cows compared with that in the low RFI cows may be attributed to the greater DMI in these cows. However, the similar MCP may reduce the differences of the MP supply between two groups corresponding to the similar milk protein yield. Numerically, though not significantly, higher ratios of MCP to RDP and MP to CP intake were obtained in the low RFI cows compared to high RFI cows, eventually resulting in higher proportion of milk protein to the dietary CP. Our results are in line with Griffin et al. [26], who found that the low RFI animals were more efficient in their utilization of MP. Thus, the greater efficiency of each step for supply of MP may contribute to the higher percentage of $\mathrm{N}$ intake into milk protein, reflective of the greater efficiency in the low RFI cows. In the current study, we did not measure the rumen passage rate that may influence $\mathrm{N}$ efficiency; a relatively small sample size may not avoid between-animal variation (in creatinine excretion) in MCP estimation. Further work with a large cohort of animals is needed to validate the findings from the current study.

Richardson and Herd [27] suggested that digestion accounted for approximately $10 \%$ of the variation in RFI. Cantalapiedra-Hijar et al. [28] found a negative correlation between DM digestibility and DM intake and suggested that DM digestibility might be higher in low RFI cattle. Other study also reported that DM and CP digestibility is greater for low RFI dairy heifers fed fresh pasture [10] and for beef cattle [12]. However, nutrient digestibility were not different between the cows with high or low RFI, though high and low RFI cows had different DMI in our study, which is in agreement with some other findings [29-32]. These discrepancies among studies could be partially attributed to the differences in the types of diets fed and the methods used. In the study of Mauch et al. [33] with pigs and the study of Potts et al. [11] with dairy cows, the relationship between feed efficiency and digestibility was less significant for diets that are easier to be digested. Using internal markers (lignin, acid-insoluble ash and indigestible NDF), Cruz et al. [32], Lawrence et al. [31] and Potts et al. [11] all failed to found an association between diet digestibility and RFI. Systematic and random errors can increase when using internal markers, which may limit the ability to detect differences in digestibility.

Though low RFI cows consumed less DM, their total VFA concentrations and ruminal $\mathrm{pH}$ are similar to those 
in high RFI group, which is consistent with other results [10, 31, 34]. However, Guan et al. [35] reported that more efficient steers tended to have a greater concentration of total VFA and butyrate compared with less efficient cattle. In the current study, no differences were observed in the concentration of total VFA and molar proportion of the individual VFAs between the two groups. The ruminal VFA profile is the results of rumen epithelial absorption and microbial fermentation, but it does not directly reflect how the animal utilizes these products [36]. Therefore, more researches are needed to investigate the effects of RFI classification on the rumen microorganisms and the ability of the rumen epithelium to absorb and metabolize VFAs.

Triglycerides are stored in fat cells and serve as a source of energy [37]. Cameron [38] reported that plasma triglycerides are useful indicators of energy status in sheep. The low RFI cows had a lower concentration of plasma triglycerides than the high RFI cows, reflective of their lower milk fat content. Moreover, Phuong et al. [39] showed the strong correlation between energy and $\mathrm{N}$ metabolism. Thus, different triglycerides indicated the different energy status between two groups and may affect $\mathrm{N}$ metabolism. Sakowski et al. [40] reported that increased ALT activity can be associated with the risk in liver disorders that are commonly caused by negative energy balance during early lactation stage. Thus, the tendency for higher ALT in high RFI cows indicates the higher health risk in these cows.

The total amounts of $\mathrm{N}$ partitioned to milk, feces and urine were not different between the two RFI cows, which agrees with the findings of Lines et al. [41]. However, Marett et al. [29] reported a reduction in urinary $\mathrm{N}$ excretion for lower RFI cow. In their study, Marett et al. [29] selected primiparous and multiparous cows based on RFI measured in calves, and neglect of parity may lead to naive assessment of the effect of RFI on nitrogen portioning. In contrast to the greater DMI by high RFI cows, cows with low RFI partitioned a greater percentage of dietary $\mathrm{N}$ into milk protein in our study. In disagreement with our study, Rius et al. [10] found no difference in $\mathrm{N}$ partitioning in milk, but cows with low RFI had lower $\mathrm{N}$ output in milk and feces and tended to have lower milk yield, compared with those of the high RFI. The conflicting relationships between $\mathrm{N}$ partitioning and RFI among studies could partially account for differences in milk yield. Rius et al. [10] demonstrated a trend for lower milk yield in low RFI cows than that of high RFI cows. Conversely, the milk yield of animals for two groups was similar in our study. Although the partitioning of $\mathrm{N}$ in feces and urine was not significantly different between the RFI phenotypes, a greater value from the low RFI cows would have been expected in terms of their higher MUN concentrations, compared with cows with high RFI. In the present study, the low RFI cows retained less $\mathrm{N}$ than the high RFI cows, which may be due to their lower DMI. Moreover, other studies with male cattle [42] and young bulls [43] have proposed that $\mathrm{N}$ retention increases due to a rise in the $\mathrm{N}$ supply. However, the ADG of two groups were not different, which is inconsistent to the differences in $\mathrm{N}$ retention. Lines et al. [41] found that the divergence in RFI is attributed to the differences of fat deposition, with extra deposition of energy as fat in high-RFI cattle with extra feed (energy) intake. Thus, high milk-protein-yielding cows selected for low RFI partitioned a greater percentage of $\mathrm{N}$ intake into milk protein, which may provide the dairy farm with more economic profit.

\section{Conclusion}

The present experiment highlights the limited variation in $\mathrm{N}$ utilization for milk production in cows producing high milk protein yields with different RFI. Several metabolic and physiological processes, including ruminal fermentation and $\mathrm{N}$ partitioning, may potentially contribute to these results. Selection for low RFI may lead to a greater proportion of $\mathrm{N}$ to milk and less to retention, which may improve the economic benefits of dairy farmers. While this study mainly focused on $\mathrm{N}$ metabolism, energy partitioning may also contribute to the variation in RFI. Thus, further research is required to better understand whether or how energy partitioning is responsible for variation in RFI in high milk protein yield dairy cows.

\section{Additional file}

Additional file 1: Table S1. Degradation constants of dry matter (DM) and crude protein (CP) based on the eq. $P=a+b[1-\exp (-c \mathrm{t})]$, where $P=$ the rate of disappearance at time $t(h), a=$ the rapidly degradable fraction in the rumen, and $b=$ the fraction slowly degraded at rate $c(c>0)$; their effective degradability (dg); and rumen undegraded protein (RUP) of the experimental diet. (DOCX $22 \mathrm{~kb})$

\begin{abstract}
Abbreviations
ADF: Acid detergent fiber; ADG: Average daily gain; ALP: Alkaline phosphatase; ALT: Alanine aminotransferase; AST: Aspartate aminotransferase; BUN: Blood urea nitrogen; BW: Body weight; CP: Crude protein; DGGS: Distillers dried grains with soluble; DM: Dry matter; DMI: Dry matter intake; ECM: Energy-corrected milk yield; IADP: Intestinally absorbable dietary protein; IDP: Intestinal digestibility of RUP; iNDF: Indigestible neutral detergent fiber; MCP: Microbial protein; MP: Metabolizable protein; MUN: Milk urea nitrogen; N: Nitrogen; NDF: Neutral detergent fiber; NEFA: Non-esterified fatty acids; PD: Purine derivatives; RDP: Rumen degradable protein; RFI: Residual feed intake; RUP: Rumen undegradable protein; SCC: Somatic cell count; TS: Total solids; VFA: Volatile fatty acids
\end{abstract}

\section{Acknowledgements}

We grateful acknowledge all staff of the Hangzhou Zhengxing Animal Industries (Hangzhou, China) for assistance in the feeding and care of the animals. We also acknowledge the members of the Institute of Dairy Science of Zhejiang University (Hangzhou, China) for help in the field sampling. 


\section{Funding}

This research was supported by grants from the National Natural Science Foundation of China (No. 31872380) and from the China Agricultural Research System (Beijing, China; No. CARS-36).

\section{Availability of data and materials}

All data generated or analyzed during this study are presented in the main manuscript.

\section{Authors' contributions}

YYX performed the experiments, analyzed the data and wrote the manuscript. JXL and WDM contributed in designing the study and revising the manuscript. ZZW were involved in the animal experiment. All authors read and approved the final manuscript.

\section{Ethics approval}

All experimental procedures involving animals were approved by the Animal Care and Use Committee of Zhejiang University (Hangzhou, China) and were followed the university's guidelines for animal research.

\section{Consent for publication}

Not applicable.

\section{Competing interests}

The authors declare that they have no competing interests.

Received: 18 December 2018 Accepted: 23 April 2019

Published online: 14 June 2019

\section{References}

1. Beever DE, Doyle PT. Feed conversion efficiency as a key determinant of dairy herd performance: a review. Aust J Exp Agric. 2007:47:645-57.

2. Connor EE, Hutchison JL, Olson KM, Norman HD. Triennial lactation symposium: opportunities for improving milk production efficiency in dairy cattle. J Anim Sci. 2012;90:1687-94.

3. Arthur PF, Archer JA, Johnston DJ, Herd RM, Richardson EC, Parnell PF. Genetic and phenotypic variance and covariance components for feed intake, feed efficiency, and other post weaning traits in Angus cattle. J Anim Sci. 2001;79:2805-11.

4. Connor EE, Hutchison JL, Norman HD. Estimating feed efficiency of lactating dairy cattle using residual feed intake. In: Hill RA, editor. Feed efficiency in the beef industry. Oxford, UK: Wiley-Blackwell; 2012. p. 159-73.

5. Haas Y, Windig JJ, Calus MP, Dijkstra J, Haan M, Bannink A, et al. Genetic parameters for predicted methane production and potential for reducing enteric emissions through genomic selection. J Dairy Sci. 2011;94:6122-34.

6. Connor EE, Hutchison JL, Norman HD, Olson KM, Van Tassell CP, Leith JM, et al. Use of residual feed intake in Holsteins during early lactation shows potential to improve feed efficiency through genetic selection. J Anim Sci. 2013:91:3978-88.

7. Jewell KA, McCormick CA, Odt CL, Weimer PJ, Suen G. Ruminal bacterial community composition in dairy cows is dynamic over the course of two lactations and correlates with feed efficiency. Appl Environ Microbiol. 2015; 81:4697-710.

8. Williams YJ, Pryce JE, Grainger C, Wales WJ, Linden N, Porker M, et al. Variation in residual feed intake in Holstein-Friesian dairy heifers in southern Australia. J Dairy Sci. 2011;94:4715-25.

9. Green TC, Jago JG, Macdonald KA, Waghorn GC. Relationships between residual feed intake, average daily gain, and feeding behavior in growing dairy heifers. J Dairy Sci. 2013;96:3098-107.

10. Rius AG, Kittelmann S, Macdonald KA, Waghorn GC, Janssen PH, Sikkema E. Nitrogen metabolism and rumen microbial enumeration in lactating cows with divergent residual feed intake fed high-digestibility pasture. J Dairy Sci. 2012:95:5024-34

11. Potts SB, Boerman JP, Lock AL, Allen MS, Vande Haar MJ. Relationship between residual feed intake and digestibility for lactating Holstein cows fed high and low starch diets. J Dairy Sci. 2017;100:265-78.

12. Nkrumah JD, Okine EK, Mathison GW, Schmid K, Li C, Basarab JA, et al. Relationships of feedlot feed efficiency, performance, and feeding behavior with metabolic rate, methane production, and energy partitioning in beef cattle1. J Anim Sci. 2006;84:145-53.
13. NRC. Nutrient requirements of dairy cattle. 7 th ed. Washington: Nat. Acad. Press; 2001

14. AOAC. Official Methods of Analysis. 17th ed. Arlington, VA, USA: Association of Official Analytical Chemists; 2012.

15. Van Soest PV, Robertson JB, Lewis BA. Methods for dietary fiber, neutral detergent fiber, and nonstarch polysaccharides in relation to animal nutrition. J Dairy Sci. 1991;74:3583-97.

16. Wang B, Mao SY, Yang HJ, Wu YM, Wang JK, Li SL, et al. Effects of alfalfa and cereal straw as a forage source on nutrient digestibility and lactation performance in lactating dairy cows. J Dairy Sci. 2014;97:7706-15.

17. Lee C, Hristov AN. Short communication: evaluation of acid-insoluble ash and indigestible neutral detergent fiber as total-tract digestibility markers in dairy cows fed corn silage-based diets. J Dairy Sci. 2013;96:5295-9.

18. Shen JS, Chai Z, Song LJ, Liu JX, Wu YM. Insertion depth of oral stomach tubes may affect the fermentation parameters of ruminal fluid collected in dairy cows. J Dairy Sci. 2012;95:5978-84

19. Hu WL, Liu JX, Ye JA, Wu YM, Guo YQ. Effect of tea saponin on rumen fermentation in vitro. Anim Feed Sci Technol. 2005;120:333-9.

20. Richardson EC, Herd RM, Archer JA, Arthur PF. Metabolic differences in Angus steers divergently selected for residual feed intake. Aust J Exp Agric. 2004:44:441-52.

21. Chen XB, Gomes MJ. Estimation of microbial protein supply to sheep and cattle based on urinary excretion of purine derivatives: an overview of technical details. Aberdeen, UK: Int. feed res. Unit, occasional Publ. Rowett research institute; 1992.

22. Oser BL. Hawk's physiological chemistry. 14th ed. New York, NY: McGrawHill; 1965

23. Leonardi C, Stevenson M, Armentano LE. Effect of two levels of crude protein and methionine supplementation on performance of dairy cows. J Dairy Sci. 2003:86:4033-42.

24. Valadares RF, Broderick GA, Valadares Filho SC, Clayton MK. Effect of replacing alfalfa silage with high moisture corn on ruminal protein synthesis estimated from excretion of total purine derivatives. J Dairy Sci. 1999;82:2686.

25. Gargallo S, Calsamiglia S, Ferret A. Technical note: a modified three-step in vitro procedure to determine intestinal digestion of proteins. J Anim Sci. 2006:84:2163.

26. Griffin WA, Rolfe K, Crawford Gl, Klopfenstein TJ, Erickson GE, Rolfe WA, et al Relationship between metabolizable protein balance, purine derivative excretion, 3-methyl histidine excretion, to feed efficiency in individually-fed heifers. J Dairy Sci. 2009:92(E-Suppl 1):153.

27. Richardson EC, Herd RM. Biological basis for variation in residual feed intake in beef cattle. 2. Synthesis of results following divergent selection. Aust J Exp Agric. 2004;44:431-40

28. Cantalapiedra-Hijar G, Abo-Ismail M, Carstens GE, Guan LL, Hegarty R, Kenny $D A$, et al. Review: biological determinants of between-animal variation in feed efficiency of growing beef cattle. Animal. 2018;12:s321-s35.

29. Marett LC, Williams SRO, Hayes BJ, Pryce JE, Wales WJ. Partitioning of energy and nitrogen in lactating primiparous and multiparous Holstein-Friesian cows with divergent residual feed intake. Anim Prod Sci. 2017:57:1499-506.

30. Thornhill JB, Marett LC, Auldist MJ, Greenwood JS, Pryce JE, Hayes BJ, et al. Whole-tract dry matter and nitrogen digestibility of lactating dairy cows selected for phenotypic divergence in residual feed intake. Anim Prod Sci. 2014:54:1460-4.

31. Lawrence P, Kenny DA, Earley B, Crews DH, McGee M. Grass silage intake, rumen and blood variables, ultrasonic and body measurements, feeding behavior, and activity in pregnant beef heifers differing in phenotypic residual feed intake. J Anim Sci. 2011;89:3248-61.

32. Cruz GD, Rodriguez-Sanchez JA, Oltjen JW, Sainz RD. Performance, residual feed intake, digestibility, carcass traits, and profitability of Angus-Hereford steers housed in individual or group pens. J Anim Sci. 2010;88:324-9.

33. Mauch ED, Young JM, Serao NVL, Hsu WL, Patience JF, Kerr BJ, et al. Effect of lower-energy, higher-fiber diets on pigs divergently selected for residual feed intake when fed higher-energy, lower-fiber diets. J Anim Sci. 2018;96: $1221-36$

34. Liang YS, Li GZ, Li XY, Lü JY, Li FD, Tang DF, et al. Growth performance, rumen fermentation, bacteria composition, and gene expressions involved in intracellular $\mathrm{pH}$ regulation of rumen epithelium in finishing $\mathrm{Hu}$ lambs differing in residual feed intake phenotype. J Anim Sci. 2017:95:1727.

35. Guan LL, Nkrumah JD, Basarab JA, Moore SS. Linkage of microbial ecology to phenotype: correlation of rumen microbial ecology to cattle's feed efficiency. FEMS Microbiol Lett. 2008;288:85-91. 
36. Hristov AN, Oh J, Firkins JL, Dijkstra J, Kebreab E, Waghorn G, et al. SPECIAL TOPICS - mitigation of methane and nitrous oxide emissions from anima operations: I. a review of enteric methane mitigation options1. J Anim Sci. 2013:91:5045-69.

37. Vernon RG, Houseknecht KL, Cronje PB. Adipose tissue: beyond an energy reserve. Ruminant Physiology Digestion Metabolism Growth \&

Reproduction; 2000.

38. Cameron ND. Correlated physiological responses to selection forcarcass lean content in sheep. Livest Prod Sci. 1992;30:53-68.

39. Phuong HN, Friggens NC, de Boer IJ, Schmidely P. Factors affecting energy and nitrogen efficiency of dairy cows: a meta-analysis. J Dairy Sci. 2013;96:7245-59.

40. Sakowski T, Kuczynska B, Puppel K, Metera E, Sloniewski K, Barszczewski J. Relationships between physiological indicators in blood, and their yield, as well as chemical composition of milk obtained from organic dairy cows. J Sci Food Agr. 2012:92:2905-12.

41. Lines DS, Pitchford WS, Bottema CDK, Herd RM, Oddy VH. Selection for residual feed intake affects appetite and body composition rather than energetic efficiency. Anim Prod Sci. 2018;58:175-84.

42. Sath K, Sokun K, Pauly T, Holtenius K. Feed intake, digestibility, and N retention in cattle fed rice straw and Para grass combined with different levels of protein derived from cassava foliage. Asian Australas J Anim Sci. 2012:25:956-61.

43. Valente EEL, Paulino MF, Marcondes MI, Dias IFT. Body composition and deposition efficiency of protein and energy in grazing young bulls. Acta Sci Anim Sci. 2014;36:215-24.

44. Orth R. Sample day and lactation report, DHIA 200. Ames, IA: Fact Sheet A-2. Mid-States Dairy Records Processing Center (DRPC); 1992.

Ready to submit your research? Choose BMC and benefit from:

- fast, convenient online submission

- thorough peer review by experienced researchers in your field

- rapid publication on acceptance

- support for research data, including large and complex data types

- gold Open Access which fosters wider collaboration and increased citations

- maximum visibility for your research: over $100 \mathrm{M}$ website views per year

At $\mathrm{BMC}$, research is always in progress.

Learn more biomedcentral.com/submissions 